Available online at

http://journal.ugm.ac.id/ifnp
INDONESIAN FOOD AND NUTRITION PROCRESS

Indonesian Food and Nutrition Progress, 2017, Vol. 14, Issue 2

\title{
Study of Microbiological Quality and Antioxidant Activity Beras Kencur Drink with Heating Process
}

\author{
Sakina Yeti Kiptiyah ${ }^{1}$, Eni Harmayani ${ }^{2)}$, Umar Santoso ${ }^{2)}$ \\ ${ }^{1)}$ Postgraduate Program of Food Science, Faculty of Agricultural Technology, Universitas Gadjah Mada, \\ Yogyakarta (+628561799683, sakinayetikiptiyah@gmail.com) \\ 2) Department of Food and Agriculture Product Technology, Faculty of Agricultural Technology, \\ Universitas Gadjah Mada, Yogyakarta \\ ${ }^{*}$ CCorresponding author, e-mail address: sakinayetikiptiyah@gmail.com
}

Received 30 Oktober 2017; Accepted 29 November 2017; Published Online 30 November 2017

\begin{abstract}
Beras kencur drink is well known as Indonesian herbal drink made from kencur (Kaempferia galanga L.) mixed with other functional ingredients through minimally-processing. The aim of this research was to evaluate microbiological quality and determine antioxidant activity of beras kencur drink with blanching and pasteurization treatment. Five samples were subjected to microbiological analysis by total plate count (TPC). Furthermore, the variation of heat treatment is blanching ( 5 and 10 minutes) and pasteurization. The sample were evaluated for $\mathrm{pH}$ value, total dissolved solids, total microbial, antioxidant activity, total phenolic content, total flavonoid content, and ferric reducing power. The results showed that five samples of beras kencur drink had varied total microbial amount while the samples treated with blanching and pasteurization had lower total microbial number. Samples with blanching kencur 5 minutes, blanching kencur 10 minutes and pasteurization had antioxidant activity of 80,30 \%RSA, 64,78 \%RSA and 58,24 \%RSA, respectively, total phenolic content $1747,17 \mathrm{mgGAE} / \mathrm{L}, 1610 \mathrm{mgGAE} / \mathrm{L}$, and 1465,13 mgGAE/L, respectively, total flavonoid content of 169,49 $\mathrm{mgEK} / \mathrm{L}, 160,36 \mathrm{mgEK} / \mathrm{L}$, and 136,31 mgEK/L, and ferric reducing power -1186,92 mgAA/L, 960,50 mgAA/L, and $897,61 \mathrm{mgAA} / \mathrm{L}$. Beras kencur drink with blanching and pasteurization process had lower total microbial number and can improve antioxidant activity.
\end{abstract}

Keywords: beras kencur, microbiological, antioxidant, total microbial

\section{Introduction}

Current phenomenon shows that more consumers are likely to get back to nature, including in choosing foods and beverages. Beras kencur drinks is a potential functional drink because it has bioactive compounds made from Kencur (Kaempferia galanga L.) mixed with some other functional ingredients. Chan et al. (2008) explains that kencur have total phenolic content of $146 \pm 9 \mathrm{mg}$ equivalent gallic acid and antioxidants which has capacity equivalent to $77 \pm 7 \mathrm{mg}$ ascorbic acid

Information process of making beras kencur drink is generally limited to historical information or empirical. There are no standarization of the formulation of beras kencur drink, which leads to inconsistent quality of taste, aroma, and especially the efficacy of beras kencur drink. Therefore, it is necessary to study the effect of heat treatment on quality of beras kencur drink 
Kiringan District, Canden, Jetis, Bantul, Yogyakarta is a district of traditional beverage production centers. It is considered to have a taste of traditional drink because it uses the original recipe. Hygiene and sanitation are important issues related to the safety of a food product. Several previous studies have shown that microbial contamination in beras kencur drink quite high due to hygiene and poor sanitation.

Treatment use heating such as blanching and pasteurization could be expected to improve the microbiological quality and antioxidant activity. Some previous studies reported that blanching can increase antioxidant activity. The antioxidant activity in beans, corn, and tomatoes as measured by DPPH increased after blanching (Kwan, et al ,. 2007). It is also consistent with research by Kwan et al. (2007) on blanched beans which resulted in improvement of antioxidant activity .Besides, pasteurization affects the survival of microbia. This study was aimed to determine the effect of blanching and pasteurization treatment against microbiological quality and antioxidant activity of beras kencur drink.

\section{Materials and Methods Materials}

Raw material used in this study were white rice (Oryza sativa L.) IR 64 obtained from Sukoharjo; kencur (Kaempferia galanga L.) varieties galesia obtained from Karanganyar; ginger (Zingiber officinale R.) varieties rubrum obtained from Purworejo; kedawung seeds (Parkia roxburgii G. Don), and brown sugar obtained from Banyumas.

Material for analysis consisted of free radical DPPH (2,2-diphenyl-1-picrylhydrazyl), ascorbic acid ( $A A=$ ascorbic acid), gallic acid ( $G A=$ gallic acid), quercetin $(Q=$ quercetin), Folin-Ciocalteu reagent, methanol pa, $\mathrm{Na} 2 \mathrm{CO} 3$ pa, pa NaNO2, AlCl3.6H2O pa, pa
$\mathrm{NaOH}, \mathrm{PCA}$ (Plate Count Agar), NA (Nutrient Agar), NB (Nutrient Broth), $\mathrm{NaCl}$ pa.

\section{Methods}

\section{Survey on Traditional Beverages Production Center}

First step of research conducted a survey in the center of the traditional beverage production Kiringan District, Canden, Jetis, Bantul, Yogyakarta. This research with a qualitative approach. The field survey to obtain basic information about traditional beras kencur drink. Information collected includes raw material and the process of making beras kencur drinks. This needs to be done as a first step to determine the primary research in the form of justification beras kencur drink.

Total Microbial Number Sample From Traditional Beverages Production Center In Kiringan.

Calculation of total microbial number sample traditional beras kencur drink conducted to determine the level of microbial contamination of the sample in Kiringan, Bantul. Analysis of the microbiological quality of the traditional drink is done by analysis 5 samples obtained from traditional beras kencur drink A, B, C, D, E contained in 5 home made beras kencur drink. 5 sample retrieval is done simultaneously with the decision of five person who using traditional drink formulations of the same material and the same time for a total microbial analysis by counting Total Plate Count beras kencur drink samples analyzed.

\section{Process of Beras Kencur Drink with Blanching Process and Pasteurization}

The main ingredient is kencur peeled and cleaned and then weighed according to formulation, the rice is washed and weighed according formulation, ginger sunti peeled and cleaned and then weighed according to 
formulation, kedawung seeds broken skin, kedawung seeds cleaned and weighed according formulation, while sugar is weighed according formulations then added water and boil. Furthermore, all ingredients blended for 3 minutes, then filtered and placed in a container of glass bottles for analysis.

Beras kencur drink are divided into 4 groups, namely:

1. Control (without treatment): beras kencur drinkwithout heating were used as control. Beras kencur drink is used as a control because of the process of making according to the process of making a traditional drink in the center of Kiringan.

2. Blanching temperature of $90^{\circ} \mathrm{C}, 5^{\prime}$ : beras kencur drink with blanching treatment at kencur at temperature of $90^{\circ} \mathrm{C}$ for 5 minutes using hot water.

3. Blanching temperature of $90^{\circ} \mathrm{C}, 10$ ': beras kencur drink with blanching treatment at kencur at temperature of $90^{\circ} \mathrm{C}$ for 10 minutes using hot water.

4. Pasteurization $100^{\circ} \mathrm{C}, 2^{\prime}$ : beras kencur drink with pasteurization at a temperature of $100^{\circ} \mathrm{C}$ for 2 minutes.

\section{Analysis of Beras Kencur Drink}

Beras kencur drink of all treatments were analyzed the $\mathrm{pH}$ value, total dissolved solid, total microbial (total plate count), antioxidant activity with DPPH, Ferric reducing power, total phenolic content and total flavonoid content.

Levels of total phenolic determined by the method of free radical scavenging capacity was determined by DPPH method with slight modifications (Ortega et al, 2008). Folin-Ciocalteu using gallic acid as standard (Lee et al, 2003). Levels of total flavonoids was determined by Colorimetric method based Aluminium Chloride (Lee et al, 2003). Activity Ferric Reducing Antioxidant Power Method (Yan et al, 2006). Total Microbial number
(Total Plate Count) (Maturin and Peeler, 2001), $\mathrm{pH}$ value, and total dissolved solids.

\section{Determination Stability of Total microbial Beras Kencur Drink During Temporary Storage}

Observation stability of traditional beras kencur drink conducted to determine the stability of the traditional beras kencur drink to the total number of microbial. Observation aims to determine the stability of damage to beras kencur drink stored at room temperature for 6 hours so as to predict the length of time the shelf life of traditional beras kencur drink that can be consumed.

\section{Result and Discussion}

Results Documentation of Traditional Beverages Center in Kiringan, Canden, Jetis, Bantul, Yogyakarta

Retrieval of data and information was obtained from traditional beverage centers Kiringan, Canden, Jetis, Bantul, Yogyakarta. Data obtained from interviews and discussions with 10 person who making traditional beras kencur drink in Kiringan The composition of traditional beverage of beras kencur based on the interview can be seen in Table 1.

\section{Calculation of Total Microbial (Total Plate Count)}

Analysis of microbiological quality traditional drink of traditional beras kencur drink $A, B, C, D$, E produced in 5 home made beras kencur drink in village centers traditional drink Kiringan, Bantul, Yogyakartawas conducted

The results showed that five samples of traditional drink derived from beras kencur Kiringan, Bantul has a total microbial (Total Plate Count) ranging from $8,5 \times 10^{5} \mathrm{CFU} / \mathrm{ml}$ to $5,3 \times 10^{8} \mathrm{CFU} / \mathrm{ml}$. The presence of microbial contamination in the traditional drink is 
Table 1. Composition of beras kencur drink in $1 \mathrm{~L}$ of water

\begin{tabular}{|l|c|}
\hline $\begin{array}{l}\text { Ingredients of beras } \\
\text { kencur drink }\end{array}$ & Amount (\%) \\
\hline White Rice & 5 \\
\hline Kencur & 20 \\
\hline Ginger & 4 \\
\hline Kedawung Seeds & 0,3 \\
\hline Brown Sugar & 25 \\
\hline
\end{tabular}

closely connected with the selection of raw materials, processing, and contamination from workers and the environment. Hygiene and sanitation is an essential condition for the traditional drink maker. According to Robinson and Tamime (1981), the maximum content of pathogenic microbes may exist on foodstuffs ready for consumption should not be more than $10^{5}$ colonies.

Treatment process with blanching and pasteurization on traditional drink of beras kencur are intended to reduce the number of the microbia, the number of microbes of bleached and pasteurized beras kencur drink were $8,4 \times 10^{3} \mathrm{CFU} / \mathrm{ml}$ and $4,1 \times 10^{3} \mathrm{CFU} / \mathrm{ml}$, respectively,.This number were lower than that of the untreated beras kencur drink. This suggests that the process of making traditional drinks can be slightly modified by blanching or pasteurization treatment to reduce the number of microbes that exist in the traditional drink of beras kencur.

\section{pH value of beras kencur drink}

Measurement of $\mathrm{pH}$ value of the traditional beras kencur drink was conducted to determine the $\mathrm{pH}$ value changes with blanching and pasteurization treatment. Figure 1 showed blanching and pasteurisation did not affect the $\mathrm{pH}$ as there was no significant different of the $\mathrm{pH}$ after the treatment. The $\mathrm{pH}$ of the beras kencur drinks were in the range of 5,67 to 6,23 .

Total Soluble Solid of Beras Kencur Drink
Total soluble solids changes as a result of the treatment process of blanching and pasteurization. Figure $\mathbf{2}$ showed that the total soluble solids sample of traditional beras kencur drink significantly different from the sample without heat treatment, ranging between $16,67^{\circ} \mathrm{Brix}-19,33^{\circ} \mathrm{Brix}$. The higher temperature used, the higher viscosity of beras kencur drink obtained. This condition is undesirable.

\section{Analysis of Antioxidant Activity of Beras Kencur Drink with DPPH method}

Antioxidants are compounds that can acts as electron donor (electron donor) or reductant. This compound has a small molecular weight, but it is able to inactivate oxidation reactions by preventing the radicals formed (Winarsi, 2007). DPPH method is a method that is simple, easy to screen radical scavenging activity of several compounds, effective and practical (Molyneux, 2003).

Pinene, kampen, carvone, benzene, eucalyptol, borneol, methyl sinnamat, pentadecan and ethyl-p-metoksinamat are compounds which exist in kencur and have antioxidant activity (Tewtraktul et al, 2005). The result shows that beras kencur drink have antioxidant activity. The highest antioxidant capacity was obtained on beras kencur drink that was blanched for $5 \mathrm{~min}$. This result is in accordance with other finding stated that blanching can increase antioxidant activity.

. The antioxidant activity of traditional beras kencur drink can be seen in Figure 3. The antioxidant capacity of 5 min blanched, 10 min blanched, pasteurized, and control were $80.30 \pm 2.26,64.78 \pm 5.11,58.24 \pm 15.39$, and $50.78 \pm 2.27 \%$ RSA.

The overall antioxidant activity of beras kencur drink is the sum of constituent ingredients in beras kencur drink. This is possible because of the interaction between the ingredients composition when mixed 


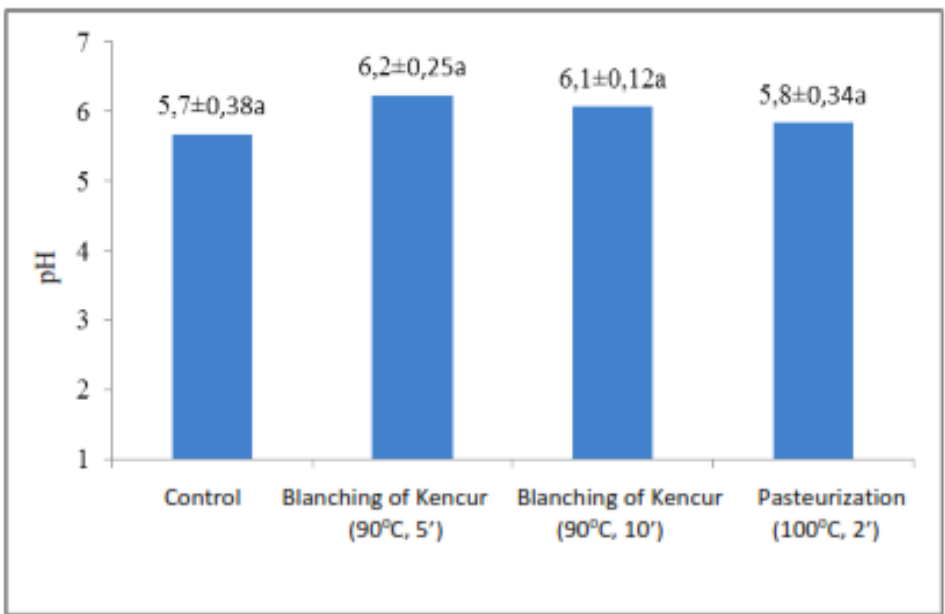

Figure 1. $\mathrm{pH}$ value beras kencur drink with variety of treatment

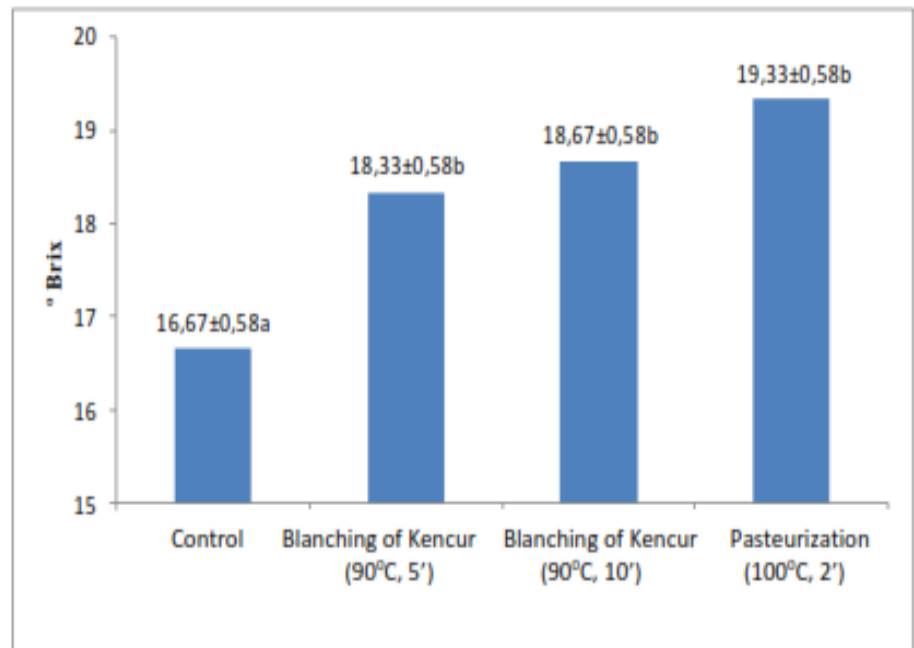

Figure 2. Total soluble solids beras kencur drink with variety of treatment

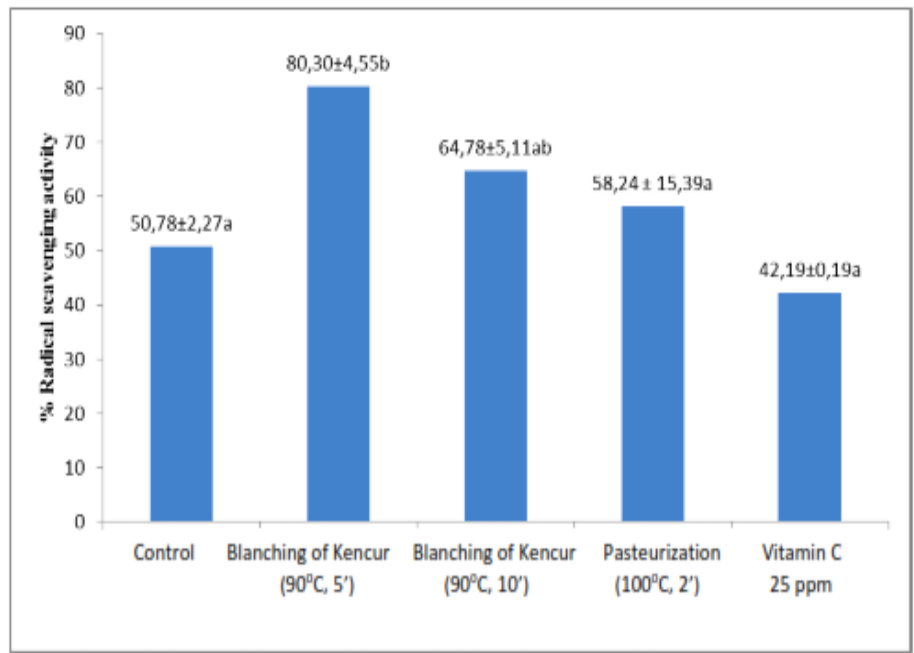

Figure 3. The antioxidant activity of beras kencur drink with variety of treatment

using a blender can increase antioxidant activity. Mixing influences resulting in increased antioxidant activity is more commonly referred to as synergism effect. 
Total Phenolic Content of Beras Kencur Drink

According Mediyaningsih (2009), the reaction between phenolic compounds with Folin-Ciocalteu reagent will produce tungsten molybdenum complex compound (in the Folin Ciocalteu reagent are sodium molybdate and sodium tungstate

The levels of total phenols in plants that were analyzed using the Folin-Ciacolteau is expressed as milligrams of gallic acid equivalents mg GAE / L. GAE is a common reference for measuring the amount of phenolic compounds contained in a material (Mongkolsilp et al, 2004). Total phenolic content of the blanching process for 5 minutes and pasteurization are 1747,17 \pm 25,64 mg GAE / L and 1465,13 \pm 76,92a mg GAE / L, respectively. Total phenolic beras kencur drinks can be seen in Figure 4.

Beras kencur drink, the main composition of rice and rhizomes of kencur contains phenolic compounds that are known to act as antioxidants. Antioxidant and polyphenol compounds have the ability to reduce the state of damaged cells, because it can capture free radicals, reduce oxidative stress, and decreased the expression of TNF- $\alpha$ causes damage to the cell (Widowati, 2008).

\section{Total Flavonoid Content of Beras Kencur Drink}

Flavonoid is in the form of glucosides (containing side chains of glucose) or in free form called aglycone which can acts as an antioxidant by donating the hydrogen atom or by chelating the metal, (Cuppett, 1954). Total flavanoid content of beras kencur drink5 minute-blanched and pasteurized drink were169,49 \pm 4,31 EK $\mathrm{mg} / \mathrm{L}$ and 136,32 \pm 8,62 EK mg / L, respectively.

The total flavonoid beras kencur drink can be seen in Figure 5. Yue and Xu (2008) reported that the. The results showed that blanching can increase the antioxidant activity as it increased flavanoid level. flavonoid is reported can act as antioxidant as it can take free radicals (Wilmsen et al, 2005).

The total flavonoid content of beras kencur drink that have been blanched for 5 minutes and 10 minutes increased significantly compared to control. This is in accordance with the result of Pujimulyani (2010) stated that Blanching on white turmeric for 5 minutes gave the highest total flavonoid levels However, the pasteurization treatment in less than 5 minutescan cause damage of flavonoids (Pinelo et al, 2004).

Flavonoids such as kaempferol and apigenin or phenolic compounds contained in the beras kencur drink increase insulin secretion, increasing glucose uptake in peripheral tissues (Pinent et al, 2008), inhibits the absorption of glucose through the activity of competitive inhibition against $\alpha$ glucosidase, $\beta$-glucosidase and $\alpha$-manosidase in the gastrointestinal tract as well as by inhibiting the absorption of glucose in the proximal renal tubules, improve glucose tolerance and inhibit gluconeogenesis and is capable of preventing the destruction of pancreatic $\beta$ cells as a result of free radicals (Coskun et al, 2005).

\section{Ferric Reducing Power of Beras Kencur Drink}

Ferric reducing power method can determine the total antioxidant content of a food which is based on the ability of these compounds to reduce $\mathrm{Fe}^{3+}$ to $\mathrm{Fe}^{2+}$. The antioxidant power of a compound is the ability to reduce other compound (Halvorsen et al, 2002). Ferric reducing power is an indicator of the potential of a compound as an antioxidant. Ferric reduction power is measured in terms of the ability of antioxidants to transform $\mathrm{Fe}^{3+}$ to $\mathrm{Fe}^{2+}(\mathrm{Kim}$, 


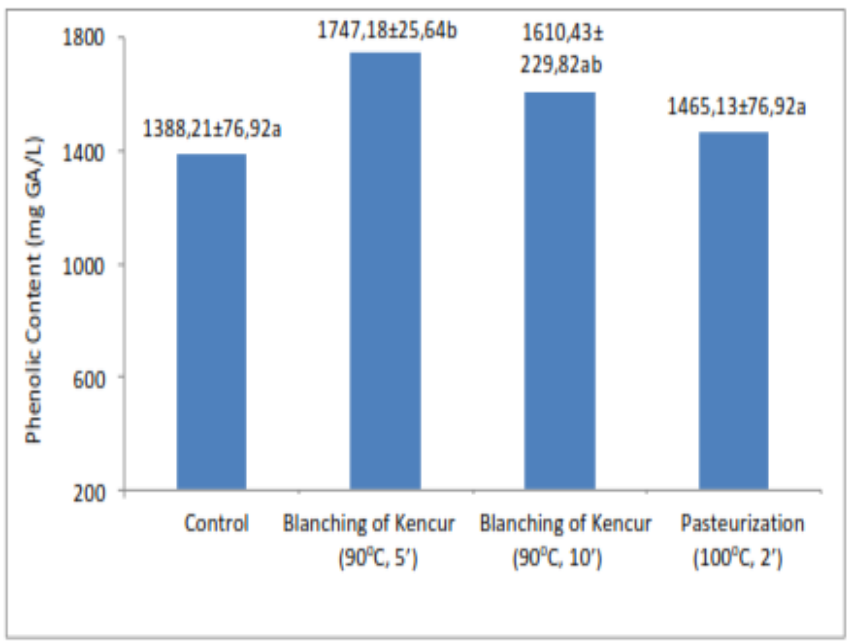

Figure 4. Total phenolic content of beras kencur drinks with variety of treatment

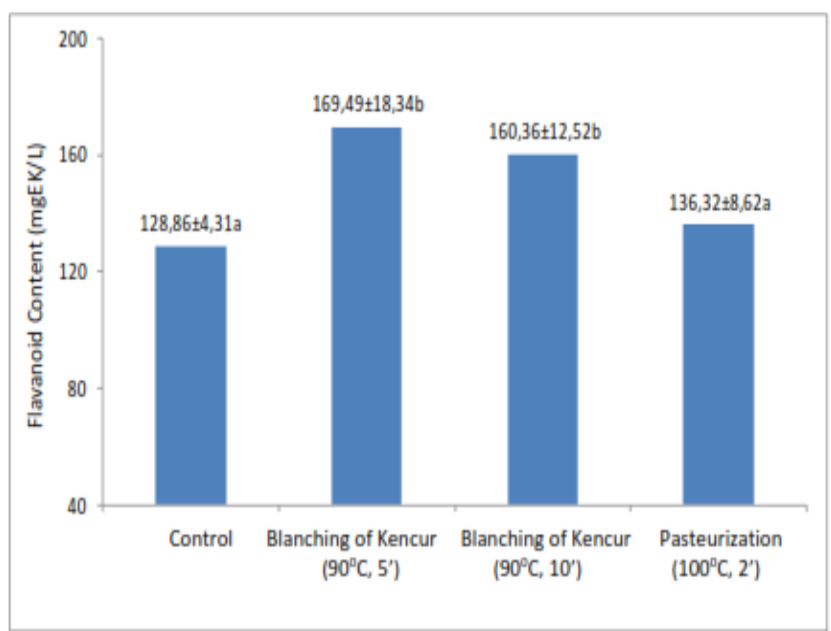

Figure 5. Total flavonoid Content Beras Kencur Drink with variety of treatment

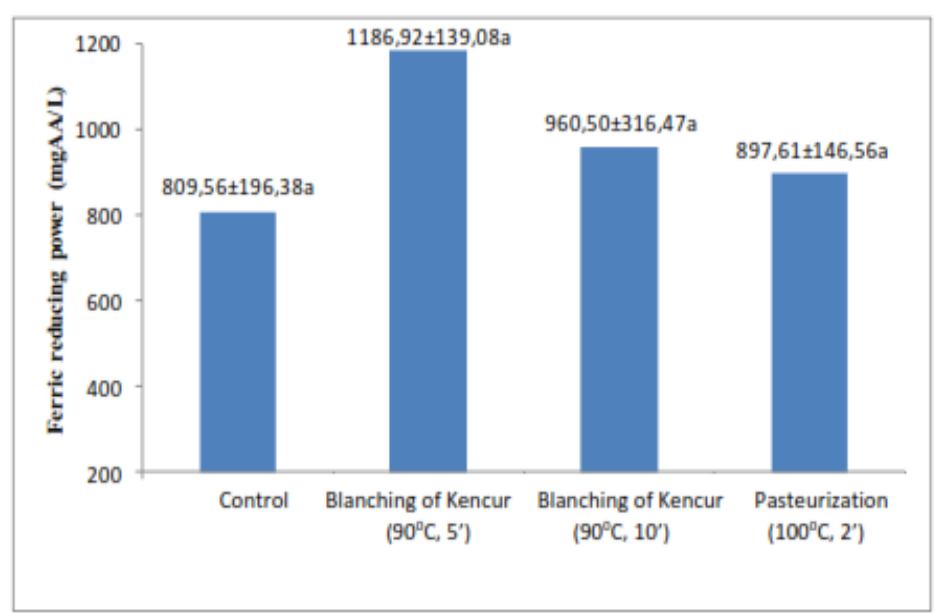

Figure 6. Ferric Reducing Power Beras Kencur Drink with variety of treatment 
Table 2. Total Plate Count beras kencur drinks during storage (log CFU/ml)

\begin{tabular}{|c|c|c|c|c|}
\hline \multirow{2}{*}{ Sample } & \multicolumn{4}{|c|}{ Storage (hour) } \\
\hline & 0 & 2 & 4 & 6 \\
\hline Control & $4,70 \pm 0,11^{\mathrm{d}}$ & $4,59 \pm 0,13^{\mathrm{c}}$ & $5,51 \pm 0,01^{\mathrm{ab}}$ & $6,85 \pm 0,06^{\mathrm{c}}$ \\
\hline $\begin{array}{l}\text { Blanching of } \\
\text { Kencur } \\
\left(90^{\circ} \mathrm{C}, 5^{\prime}\right)\end{array}$ & $4,06 \pm 0,01^{b}$ & $4,18 \pm 0,01^{b}$ & $5,49 \pm 0,13^{\mathrm{ab}}$ & $6,49 \pm 0,13^{b}$ \\
\hline $\begin{array}{l}\text { Blanching of } \\
\text { Kencur } \\
\left(90^{\circ} \mathrm{C}, 10^{\prime}\right)\end{array}$ & $3,83 \pm 0,04^{\mathrm{c}}$ & $4,18 \pm 0,11^{\mathrm{b}}$ & $5,59 \pm 0,13^{b}$ & $6,42 \pm 0,03^{\mathrm{b}}$ \\
\hline $\begin{array}{l}\text { Pasteurization } \\
\left(100^{\circ} \mathrm{C}, 2^{\prime}\right)\end{array}$ & $3,51 \pm 0,01^{\mathrm{a}}$ & $3,52 \pm 0,03^{\mathrm{a}}$ & $5,28 \pm 0,11^{\mathrm{a}}$ & $6,11 \pm 0,16^{\mathrm{a}}$ \\
\hline
\end{tabular}

Note : The value followed by the same letter in the column shows are not significant ( $\alpha=5 \%$ as measured by duncan test).

2005). According to Hart (1983), phenolic compounds are compounds that easily oxidized so it is as a reducing agent. Reduction of $\mathrm{Fe}^{3+}$ is often applied as an indicator of electron donation activity which is an essential mechanism of antioxidant capacity.

Figure 6 showed that the ferric reducing power of beras kencur drink was highest in kencur blanching treatment for 5 minutes with the amount of $1186,92 \pm 139,08$ $m g A A / L$ and the lowest was obtained in the control ( 809,56 $\pm 196,38 \mathrm{mg} \mathrm{AA} / \mathrm{L}$ ). Vitamin C is used as a standard analysis of reducing power because vitamin $\mathrm{C}$ is known as a strong reducing agent and is often applied as a comparison in the test compound reducing power (Ebrahimzadeh et al, 2008). These results relate to the total phenolic content traditional beras kencur drink, the higher the levels of total phenols, the higher the reducing power.

\section{Stability of Beras Kencur Drink}

The microbiological quality of a food is determined by the amount of bacteria present in the food ingredients. Microbiological quality of the food will determine the shelf life of the product total plate count beras kencur drinks was conducted at $0,2,4$, and $6 \mathrm{~h}$ of storage. The timing of this is based on the consumption of beras kencur drink in fresh condition or temporary storage. The results are presented in Table 2. Beras kencur drink with blanching and pasteurization treatment showed a decrease of total microbial compared to control

Microbial growth in the beras kencur drink can reduce the quality and food safety, which is marked by changes in taste, aroma, color, consistency and appearance. TPC number of traditional beras kencur drink closely related to hygiene and sanitation. Temperature pasteurization can affect the survival of microbes that are sensitive to the heat, so the number is reduced. This occurs because of differences in bacterial resistance to heat. This is in accordance with the research of Sunarlim and Widaningrum (2005) stated that pasteurized milk has a lower TPC than fresh milk.

Source of contamination could come from raw materials, equipment, processing and working conditions (Seow and Gwee, 1997). Bacteria are more resistant to heating than those of molds and yeast. No growth of fungi was observed on heating at $65^{\circ} \mathrm{C}$ for 10 minutes. Similar to other finding, mold could be deactivated by heating at $55^{\circ} \mathrm{C}$, whereas 
bacteria requires higher temperature $\left(70^{\circ} \mathrm{C}\right)$ to be inactivated (Ejechi et al, 1997).

\section{Conclusion}

Beras kencur drink samples obtained from Kiringan, Bantul has a total microbial (Total Plate Count) that varies ranging from $8,5 \times 10^{5}-5,3 \times 10^{8} \mathrm{CFU} / \mathrm{ml}$, while samples with blanching and pasteurization treatment had lower total microbial, $8,4 \times 10^{3} \mathrm{CFU} / \mathrm{ml}$ and $4,1 \times 10^{3} \mathrm{CFU} / \mathrm{ml}$. Samples with blanching treatment of 5 minutes, 10 minutes blanching and pasteurization has antioxidant activity, total phenolic content, total flavonoid content, and ferric reducing power higher and significantly different than the control sample. Beras kencur drink with blanching and pasteurization process had lower total microbia and can improve antioxidant activity compared with control.

\section{References}

Chan, E.W.C., Lim, Y.Y., Wong, L.F., Lianto, F.S., Wong, S.K., Lim, K.K., Joe, C.E., and Lim, Y.T. 2008. Antioxidant and tyrosinase inhibition properties of leaves and rhizomes of ginger species. J Food Chem 109 : 477-483.

Kwan, Y., Apostolidis, I., and Shetty, K. 2007. Traditional Diet of Americans For Management of Diabetes And Hypertension. J Medicinal Food. 10: 266-275.

Lee, K.W., Kim, W.J., Lee H. J., Lee, C.Y. 2003. Cocoa Has More Phenolic Phytochemicals and a Higher Antioxidat Capacity than Teas and Red Wine. Journal of Agricultural Food Chemistry 51: 7292-7295.

Maturin, L., Peeler, J.T. 2001. Aerobic Plate Count. in: Bacteriological Analytical Manual Online. Center for Food Safety and Applied Nutrition. Food and Drug Administration. US.

Ortega, N., Romero, M., Macia, A., Reguant, J., Angles, N., Morello, J., and Motilva, M.
2008. Obtention and Characterization of Phenolic Extracts from Different Cocoa Sources. Journal of Agricultural. Food Chemistry 56: 9621-9627.

Yan, L.Y., Teng, L.T. and Jhi, T.J. 2006. Antioxidant properties of guava fruit: comparison with some local fruits. Sunway Academic Journal 3: 9-20.

Robinson,T. 1995. Kandungan Organik Tumbuhan Tinggi,Terjemahan Kokasih Padmawinata. Penerbit ITB. Bandung.

Molyneux, P. 2004. The use of the stable free radical diphenylpicryl-hydrazyl (DPPH) for estimating antioxidant activity. Songklanakarin J Sci Technol 26 (2): 211-219.

Winarsi, H. 2007. Antioksidan Alami \& Radikal Bebas: Potensi dan Aplikasinya dalam Kesehatan. Penerbit Kanisius. Yogyakarta.

Tewtrakul, S., Yuenyongsawad, S., Kummee, S., and Atsawajaruwan, L. 2005. Chemical components and biological activities of volatile oil of Kaempferia galanga Linn. Songklanakarin J Sci Technol 27 (2): 503-507.

Medyaningsih, E. 2009. Potensi Ampas Nanas Sebagai Sumber Antioksidan: Karakterisasi Antioksidan Ampas Nanas dari Nanas yang telah Mendapat Perlakuan Blanching. Skripsi. Fakultas Teknologi Pertanian, Universitas Katolik Widya Mandala. Surabaya.

Pujimulyani, D., Raharjo, S., Marsono, Y., dan Santoso, U. 2010. Aktivitas Antioksidan dan Kadar Senyawa Fenolik pada Kunir Putih (Curcuma mangga Val.) Segar dan Setelah Blanching. Jurnal Agritech 30 (2): 68-74.

Pinelo, M., Manzocco, L., Nuñez, M.J. and Nicoli, M.C. 2004. Solvent effect on quercetin antioxidant capacity. Food Chemistry 88: 201-207.

Widowati. 2008. Potensi Antioksidan sebagai Antidiabetes. Journal KM. 7(2:)1-11.

Cuppett, S., Schrepf, M. and Hall, C. 1954. Natural Antioxidant - Are They Reality. 
Dalam Foreidoon Shahidi: Natural Antioxidants, Chemistry, Health Effect and Applications. AOCS Press. Champaign. Illinois: 12-24.

Coskun, O., Kanter, M., Korkmaz, A., and Oter, S. Quercetin, a flavonoid antioxidant, prevents and protects streptozotocin-induced oxidative stress and beta-cell damage in rat pancreas. Pharmacol Res 51(2):117-23.

Pinent, M., Castell, A., Baiges, I., Montagut, G., and Arola, L. 2008. Bioactivity of Flavonoid on Insulin-secreting Cells. Compr Rev Food Sci Food Safety 7: 299308.

Yue, X. dan Xu, Z. 2008. Changes of anthocyanins, anthocyanidins, antioxidant activity in bilberry extract during dry heating. Journal of Food Science 73: 494-499.

Wilmsen, P.K., Spada, D.S., and Salvador, M. 2005. Antioxidant activity of flavanoid hesperidin in chemical and biological systems. J. Agric. Food Chem., 53,47574761.

Halvorsen, B. L., Holte, K., Myhrstad, M.C.W., Barikmo, I., Hvattum, E., Reberg, S. F., Wold, A. B., Haffner, K., Baugerod, H., Andersen, L. F., Moskaug, O., Jacobs, D. R., and Blomhoff, R. 2002. A Systematic Screening of Total Antioxidant In
Dietary Plants. J. Nutrition. 132 : 461471.

Hart, H. 1983. Kimia Organik. Houngton Mifflin Co. Michigan State University. USA.

Kim, O.S. 2005. Radical Scavenging capacity and antioxidant activity of the $E$ Vitamer fraction in rice bran. Journal of Food Science 70: 208-213.

Ebrahimzadeh, M.A., Pourmorad, F. and Hafezi, S. 2008. Antioxidant activities of iranian corn silk. Turkish Journal of Biology 32: 43-49.

Seow, C.C., and Gwee, C.N. 1997. Coconut milk: Chemistry and technology. International Journal of Food Science and Technology. 32:189-201.

Ejechi, B.O., Souzey,J.A and Akpomedaye, D.E. 1998. Microbial stabillity of mango juice preserved by combined application of mild heat and extracts of two tropical spices. J.Food Protection 61(6): 725727.

Widaningrum dan Sunarlim, R. 2005. Cara Pemanasan, Suhu dan Lama Penyimpanan Terhadap Masa Simpan Susu Kambing. Seminar Nasional Teknologi Peternakan dan Veteriner. 